\title{
Batı Akdeniz Bölgesindeki orman ürünleri sanayinin sertifikasyona yönelik kararı ve bu kararın etkileri
}

Certification decision of forest products industry in the Western Mediterranean Region of Turkey and the effects of this decision

\author{
Ersin YILMAZ \\ Süleyman ALKAN ${ }^{1}$ (D) \\ Arif KAYACAN $^{1}$ (D) \\ Yunus BAYIR ${ }^{1}$ \\ Zafer MAVI ${ }^{1}$
}

' Batı Akdeniz Ormancılık Araştırma Enstitüsü Müdürlüğü, Antalya

Sorumlu yazar (Corresponding author) Ersin YILMAZ

eyilmaz33@gmail.com

Geliş tarihi (Received)

02.03 .2020

Kabul tarihi (Accepted)

14.05.2020

Sorumlu editör (Corresponding editor)

Güven KAYA

guvenkaya@ogm.gov.tr

Atıf (To cite this article): YILMAZ, E, ALKAN, S, KAYACAN, A, BAYİR, Y, MAVİ, Z . (2020). Batı Akdeniz Bölgesindeki orman ürünleri sanayinin sertifikasyona yönelik kararı ve bu kararın etkileri. Ormancılık Araştırma Dergisi , 7 (2), $147-161$

DOI: https://doi.org/10.17568/ogmoad. 697015

Creative Commons Atıf Cüretilemez 4.0 Uh Atif Türetilemez 4.0 Uluslarara
Lisansı ile lisanslanmıștır.

\section{$\ddot{O} z$}

$\mathrm{Bu}$ çalışmanın amacı; Batı Akdeniz Bölgesindeki orman ürünleri sanayinin sertifikasyona yönelik kararı ve bu kararın etkilerini incelemektir. Araştırmada imalatçıların sertifikalı olup olmama karar1 vereceklerinde kullanabilecekleri karar sürecini modellemek için "Analitik Hiyerarşi Süreci (AHS)" tekniği kullanılmıştır. Araştırmada iki hedef kitle bulunmaktadır. Bunlar; Batı Akdeniz Bölgesindeki odun esaslı sertifikalı olmayan orman ürünleri imalatçıları ve sertifikalı orman ürünleri imalatçılarıdır. Sosyal Güvenlik Kurumu (SGK) kayıtlarına göre çalışan sayısı 30 kişiden fazla, orta ve büyük ölçekli olan 10 sertifikalı olmayan orman ürünleri imalatçıları çalışmaya dâhil edilmiştir. Sertifikalı orman ürünleri imalatçıları olarak ise araştırmanın yürütüleceği zamanda bağımsız bir üçüncü taraf sertifikasyon kuruluşu olan FSC (Orman Yönetim Konseyi) tarafından sertifikasyona tabi tutulmuş orman ürünleri üreten 4 imalatçı alınmıştır. Sertifikalı olmayan imalatçılar için hesaplanan AHS tekniği çıktısı, hem sertifikalı hem sertifikalı olmayan orman ürünü üretmedir. Bununla birlikte AHS tekniği, sertifikalı imalatçıların sadece sertifikalı orman ürünü üretmesi gerektiğini ortaya koymuştur.

Anahtar Kelimeler: AHS tekniği, Batı Akdeniz Bölgesi, çok kriterli karar verme, orman ürünleri sanayi, sertifikasyon

\begin{abstract}
The objective of this study was to examine the certification-directed decision of the forest products industry in the Western Mediterranean Region of Turkey and the effects of that decision. In the second part of the research, "the Analytic Hierarchy Process (AHP)" technique was used to model the decision process that manufacturers can use when deciding whether to be certified or not. There are two target groups in the research. These are wood-based non-certified forest products manufacturers and certified forest products manufacturers in the Western Mediterranean Region. According to the Social Security Institution (SGK) records, 10 non-certified forest products manufacturers with more than 30 employees, medium and large-scale, were included in the study. As certified forest products manufacturers, 4 manufacturers producing forest products that were certified by FSC (Forest Stewardship Council), an independent third party certification company, were taken at the time of the study. AHP technique outcome calculated for the non-certified manufacturers is to produce both certified and non-certified forest products. However, the AHP technique outcome has revealed that certified manufacturers should produce only certified forest products.
\end{abstract}

Key Words: AHP technique, certification, forest products industry, multi criteria decision making, Western Mediterranean Region 


\section{Giriș}

Orman sertifikasyonu, 1990'lardan bu yana sürdürülebilir orman yönetiminin bir aracı olarak hızla kabul edilmiştir (Durst ve ark., 2006; Stevens ve ark., 1998). Dünya ormanlarının durumunu iyileştirme yönündeki çabaları sonucu çevresel hareket, sürdürülebilir şekilde üretilmiş odun hammaddesi ürünlerinin sertifikasyonunu benimsemiştir.

Çevresel ürünlere yönelik talep bazı orman ürünleri firmalarının sertifikasyon programlarına kaydolmaya başlamasının sebeplerinden birisidir (Bartley, 2003; Anderson ve Hansen, 2004). Birleşik Devletlerde sertifikalı orman ürünlerine yönelik talep, ülkenin Pasifik Kuzey Batıdaki kuzey benekli baykuşa yönelik olumlu ortam oluşturan yaşlı ormanlara yönelik tartışmalardan ortaya çıkmiştır (Hubbard ve Bowe, 2005; Bowyer, 2008). FSC (Forest Stewards Council), PEFC (Pan European Forest Certification System) gibi üçüncü-taraf kuruluşlar orman yönetim uygulamalarını ve süreçlerini karşılaştırmak suretiyle orman arazilerini ve orman ürünlerini sertifikalandırmaktadır (Vlosky ve Ozanne, 1998; Rametsteiner ve Simula, 2003). Bu programlar asil olarak orman arazileri üzerinde kullanılan yönetim uygulamalarının sertifikasyonunu sağlasa da, bunun yanında $\mathrm{CoC}$ sertifikasyonu yoluyla orman ürünlerinin işlenmesi ile ilgili sertifikasyonu da sağlayabilmektedir (Hubbard ve Bowe, 2005).

Odun hammaddesi ürünlerinin sertifikasyonu bir firmanın çevresel olarak yararlı uygulamalarının incelenmesini içermektedir. Her ne kadar sürdürülebilir şekilde yönetilen orman ürünlerinin sertifikasyonu çevresel hareketin ilgi ve kaygıları için umut veren bir çözüm olsa da bu sürecin sanayide benimsenmesi yavaş olmuştur. Uzmanlar 2000'li yılların başında piyasada mevcut sertifikalı ürün yüzdesinin, odun hammaddesi ürünlerine yönelik toplam talebin \%1'inden daha az olduğunu tahmin etmiştir (Kiekens, 2000). Her ne kadar tüketiciler sertifikalı ürün talep etseler de hali hazırda piyasadaki tüketiciler sertifikalı ürünler için daha fazla ödeme yapmaya istekli değillerdir (Hansen, 1997).

Dünyada birçok tüketici ormanların durumu ve odun hammaddesi üretimi konusunda ilgi ve kayg1larını ifade etse de bu tedirginliklerinin sebeplerini ortaya koyamamaktadır. Bunun yerine yaşlı ormanlar ve ormansızlaşmaya yönelik muğlak düşüncelerini, kaygılarının nedeni olarak öne sürmektedir. Aynı zamanda orman ürünleri sanayisindeki birçok imalatçı, ormanların iyi yönetilmesi ve tüketici talebinin yeterli olmaması nedenleriyle, sertifikasyonun gereksizliğini savunmaktadır (Alt, 2001).
Dünya ormanlarının durumunu iyileştirmek ve dünyada kullanıma yönelik odun hammaddesini kontrol etmek yönündeki çabalar sonucu çevresel hareket, sürdürülebilir şekilde üretilmiş orman ürünlerinin sertifikasyonunu benimsemiştir. Her ne kadar sürdürülebilir şekilde yönetilen orman ürünlerinin sertifikasyonu çevresel hareketin ilgi ve kaygıları için umut veren bir çözüm olsa da bu sürecin sanayide benimsenmesi yavaş olmuştur.

Ormancılıkta sertifikasyon hareketi hala gelişme aşamasındadır ve birçok oduna dayalı imalatçı bunun uzun dönemde sağlayacağı faydalar konusunda kuşkulara sahiptir. Sertifika yapan kuruluşlar bu hareketi özendirmeye çalışsalar da büyük oranda yanlış bilgilenme ve yanlış anlamalardan dolayı bu hareketi yaygınlaştırmak güçtür.

Küresel ölçekte imalatçıların bakış açısından orman sertifikasyonunun faydaları (Jayasinghe ve ark.., 2007; Ratnasingam ve ark., 2008; Stevens ve ark., 1998; Vlosky ve Ozanne, 1998) yanında tüketicilerin sertifikalı ürünlere yönelik tercihleri ve davranışlarını (Aguilar ve Vlosky, 2007); Bigsby ve Ozanne, 2002; Forsyth ve ark., 1999; Kozak ve ark., 2004; Mohamed ve Ibrahim, 2007; Ozanne ve Vlosky, 1997 ve 2003) inceleyen çok sayıda çalışma bulunmaktadır.

Aynı zamanda orman sertifikasyonunun etkinliği (Ebeling ve Yasue, 2009; Tikina ve Innes, 2008) ve orman sertifikasyonunun maliyet ve faydaları (Chen ve ark., 2010) dâhil orman sertifikasyonunun diğer pek çok yönü de incelenmiştir. Bunun yanında orman ürünlerinin pazarlanması alanında orman sertifikasyonu ve sertifikalı orman ürünleri konusunda artan sayıda çalışmalar yapılmaktadır. Bazı araştırmacılar sertifikalı ürünlere yönelik fazladan fiyat ödeme istekliliğini incelemiştir (Jensen ve ark., 2003; Ozanne ve Vlosky, 2003). Diğer bir çalışma aktüel satın alma davranışını ölçmek için deneysel bir yaklaşım kullanmıştır (Anderson ve Hansen, 2004). Öte yandan orman ürünleri firmalarının bakış açısını yansıtan çalışmalar nispeten daha azdır. Hansen (1997) tarafından Kuzey Amerika'da pazarlama stratejilerinde orman sertifikasyonunun rolü incelenmiştir. Stevens ve ark (1998), sertifikalı orman ürünlerinin piyasa özelliklerini belirlemek için Amerikalı imalatçıları ele almıştır. Hubbard ve Bowe (2005), orman ürünleri imalatçılarının sertifikalı orman ürünleri konusundaki görüş ve deneyimlerini incelemiştir. Vidal ve ark. (2005), Kanada ve Birleşik Devletlerdeki orman ürünleri sanayindeki sertifikasyonun durumunu araştırmıştır. Bununla birlikte bu çalışmaların çoğunluğu ABD, Kanada ve Avrupa ülkelerinde yapılmıştır. 
Buna karşın çalışmayla doğrudan veya dolaylı olarak ilgili ülke içinde yapılan çalışmalara ilişkin özet bilgiler ise aşağıda verilmiştir. Geray (1999) tarafından, sertifikalandırma ve ekolojik etiketleme konusunda gerek duyulan çeşitli araştırma ve incelemeler yapılmadan önceki aşamaya ilişkin ülkedeki ilk rapor kaleme alınmıştır. Türker ve ark., (2001) ormancilıkta sertifikalandırmanın ilk olarak sivil toplum örgütleri tarafından gündeme getirildiğini belirtmiştir. Durusoy (2002) orman sertifikalandırmasının, doğa-dostu tüketiciler ile ürünlerini pazara daha büyük bir avantajla sunmak isteyen üretici taraflar arasında güçlü bir ilişki kurmak suretiyle, ormanların daha iyi yönetilmesini teşvik etmek ve ormancılık faaliyetlerinin sürdürülebilir kalkınma ilkelerine uygun olarak yürütülmesine yardımcı olmak amacıyla geliştirilmiş yeni bir araç olduğunu ifade etmiştir. İlter ve Ok (2004) tarafindan çevresel ilginin tüketici kararlarında etkisinin artması ile beraber, literatürde yeşil satın alma (green buying), yeşil pazarlama (green marketing), çevresel pazarlama (environmental marketing) ve yeşil işletmecilik (green business) terimlerinin görülmeye başlandığ1 belirtilmiştir. Öte yandan Vurdu ve ark., (2007)'ye göre sertifika kurumunun etiketini taşıyan ürünlerin gerçekten sertifikalı bir ormandan geldiğini garanti etmek için bir takip sürecinin ve kontrol sisteminin uygulanması zorunluluğu ortaya çıkmaktadır. Bu sisteme Denetim ve Gözetim Zinciri Sistemi (Chain of Custody, CoC) denilmektedir. Akyol ve Üçok (2008)'e göre sertifikasyon işlemi, ulusal ve uluslararası ölçeklere göre uygulama şekilleri ve standartları olan kuruluşlar tarafından yapılır. Türkoğlu (2009)'e göre ormanların rasyonel yönetilmesini ve fonksiyonlarını bugün ve gelecekte koruyacak bir şekilde yararlanmayı amaçlayan sürdürülebilir orman yönetimi ile orman kaynaklarının oluşumundan tüketimine kadar geçirdiği süreçleri kayıt altına alan ve ormanın nasıl yönetildiğini bağımsız bir organ tarafından belirli çevresel, sosyal ve ekonomik ölçütlere bağlı olarak değerlendiren ve son ürünü etiketlendiren sertifikasyondur. Şener (2009)'a göre sertifikasyonla ilgili girişimler 1990‘11 yıllarda yoğunluk kazanmıştır. Bu girişimler; sertifikasyon ve etiketleme sistemlerinin tanımlanması amacıyla ormanların yönetimi, işletimi, koruma ve gözetim zinciri ile ilgili konularda birtakım standartların saptanması, gösterge ve ölçütlerin ortaya konulması faaliyetlerini kapsamaktadır. Şener (2009)'da sertifikasyonda, bir orman işletmesi bünyesinde yapılan tüm orman işletmeciliği faaliyetlerinin bağımsız bir kurum tarafından belirlenen standartlara göre değerlendirilmesi ve teftiş edilmesini mümkün kılan bir sürecin ifade edildiği belirtilmektedir. Şener (2009) ve Şener ve ark., (2011)'de Göksun ve Andırın Devlet Orman
İşletme Müdürlüklerinin ormanc1lık faaliyetlerini sürdürülebilir şekilde yönetip yönetmediği, OGM kriter ve göstergelerine göre sertifikasyon yapabilen bir kurum var kabul edilerek incelenmiş ve bu birimlerin sertifika alabilirliği tartışılmıştır. Karagöz (2010)'a göre sertifikasyonda iki önemli başlık vardır. Bunlar; 1) orman yönetiminin sertifikasyonu (forest management certification) ve 2) odun ve odun ürünlerinin sertifikasyonu yani denetim ve gözetim sertifikasyonu (chain of custody/ CoC)'dur. Türkoğlu (2011)'de, sertifikalı orman kaynaklarının ve sertifikalı orman ürünleri ticaretinin Türkiye'deki mevcut durumu, orman endüstri işletmelerince sertifikalı hammadde temini, işleyişi ve prosedürlerine yer verilmiştir. Karagöz ve ark., (2011) tarafından denetim ve gözetim zinciri sertifikasyonu, odun ve odun ürünleri endüstrisinde sertifikasyon, sertifikasyon süreçleri, ülkemizdeki ve dünyadaki durum, denetim mekanizması ve sertifikalı ürün pazarlanması hakkında bilgiler verilmiştir. Türkoğlu ve Tolunay (2013)'de başta kereste olmak üzere orman ürünleri ithal ederek, bu ürünleri iç ve diş piyasaya pazarlayan özel sektör işletmelerinin, sertifikalı orman ürünlerine ilişkin görüşleri araştırılmıştır. Genç (2014)'de FSC sistemine göre sertifikalandırılmış Kastamonu Orman Bölge Müdürlüğüne bağl1 5 orman işletme müdürlügündeki sertifikalandırma sürecinde karşılaşılan sorunlar ortaya konulmuş ve bu sorunlara çözüm önerileri getirilmeye çalışılmıştır. Şensöz (2014)'de orman sertifikasyonu konusunda genel bir değerlendirme yapılarak sertifikasyon türleri ve sertifikasyon kuruluşları anlatılmış, Türkiye'de ve dünyada yaşanan gelişmeler ile bugün itibariyle gelinen son nokta irdelenmiş, sertifikasyonun ormancılık sektörü ve ormancılık politikası açısından gerekliliği açıklanmıştır. Türkoğlu ve Tolunay (2014)'de Muğla Orman Bölge Müdürlüğü sorumluluk alanındaki ormanlarda, FSC sertifikasının alınması sürecinde karşılaşılan güçlükler ile sertifikanın alınması sonucu oluşan etkileri sosyal, çevresel ve ekonomik açıdan irdelenmiştir. Komut (2016) tarafından yapılan çalışma, Türkiye'de devlet orman işletmeleri ve orman ürünleri endüstrisi işletmeleri yönetici ve çalışanlarının orman ve orman ürünleri sertifikasyon farkındalığının çeşitli değişkenlerle incelenmesi amacıyla ele alınmıştır. Şener (2016)'da sürdürülebilir orman yönetimi, ölçüt ve göstergeler ile oluşum süreçleri ve sertifikasyon konularında kavramsal açıklamalar yapılmıştır. Dursun ve Daşdemir (2016) tarafından FSC sertifikasyon sürecinin Keles Orman İşletmesindeki ekolojik, ekonomik, sosyal ve yönetsel etkilerini incelemek ve değerlendirmek amacıyla bir çalışma gerçekleştirilmiştir. Koçak (2016) ve Koçak ve ark., (2017)'de Türkiye'deki FSC sertifikalı orman kaynaklarının sertifikasyon süreci sonrasındaki mevcut 
durumu ve Türkiye ormancılığına katkıları incelenmiştir. Koç (2016)'da sürdürülebilir kalkınma için sürdürülebilir orman yönetiminin önemine vurgu yapılarak Türkiye'de orman ürünleri tüketicilerinin sürdürülebilir orman yönetimi algıları, sertifikasyon farkındalıkları, sertifikalı ürünleri tercih edecek bir tüketici kitlesinin varlığını araştırmak amaçlanmıştır. Dursun ve Daşdemir (2017) tarafından yapılan çalışmada FSC sertifikasyon sürecinin İnegöl Orman İşletmesindeki ekolojik, ekonomik, sosyal ve yönetsel etkileri değerlendirilmiştir.

Sertifikalı olma kararı bir firma üzerinde yoğun bir etkiye sahip olan önemli bir karardır. Bu kararın önemli bileşenlerini belirlemek için yapılacak bir çözümleme, imalatçıların bu kararı nasıl ele aldıklarını anlamayı kolaylaştıracak ve bu karar verileceği zaman yardımcı olacaktır. Nihayet sertifikasyonun Türkiye için nispeten yeni bir hareket olmasından dolayı, sertifikalı olma kararının gerçek dünyadaki sonuçlarını anlamak önemlidir. Bu çalışma bu bilgi ihtiyaçlarına da cevap vermek üzere hazırlanmıştır.

Araştırmada imalatçıların sertifikasyona tabi olup olmama kararına nasıl yaklaştıkları incelenmiştir. Karar vericilerin sertifikasyon kararına nasıl yaklaştıklarının incelenmesi ve karar vermede onlara bir kılavuzun sunulması, bu kararla yüz yüze gelen ve ne yapacağını bilemeyen imalatçılara önemli bir katkı sağlayacaktır.

Araştırmanın amaçları; sertifikalı ürün üretip üretmeme kararı verileceğinde, orman ürünleri imalatçılarının karar verme sürecinde dikkate alabileceği önemli kriterleri belirlemek, AHS tekniği kullanılarak imalatçıların karar verme sürecini modellemek ve sertifikalı ve sertifikalı olmayan imalatçıların karar verme sürecindeki olası farklılıkları ortaya koymaktır. Kısacası araştırmanın amacı: Batı Akdeniz bölgesi orman ürünleri imalatçılarının sertifikasyona yönelik karar verme sürecini modellemek olarak belirlenmiştir.

\section{Materyal ve Yöntem}

\subsection{Materyal}

Araştırma amaçlarına ulaşmak için bir AHS karar verme modeli ve buna uygun bir "bilgi formu" geliştirilmiştir. Bu model ve bilgi formu, iki öbeğin (sertifikalı ve sertifikalı olmayan orman ürünü imalatçıları) karar verme sürecine nasıl yaklaşt1$\breve{g}_{1}$ konusunda farklılık olup olmadığını belirlemek için her iki öbeğe de uygulanmıştır.

\subsection{Yöntem}

Çalışmadaki karar verme sürecini modellemek için "Analitik Hiyerarşi Süreci (AHS)" tekniği kullanıl- mıştır. AHS kullanmanın faydası, kararı önemli elemanlara ayırma ve bu elemanların ilişkisini matematiksel olarak tanımlama yönünde araştırmacılara imkân tanımasıdır.

Araştırmadaki veri toplama ile sertifikasyon akımı kapsamındaki karar üzerinde etkili kriterler ortaya konmuştur. $\mathrm{Bu}$ bilgi, kullanılan AHS modelinin yapısı ve kriterlerinin geliştirilmesi açısından faydalı olmuştur.

\subsubsection{Hedef kitle}

Araştırmada iki hedef kitle bulunmaktadır. Bunlar; Batı Akdeniz Bölgesindeki odun esaslı sertifikalı olmayan orman ürünleri imalatçıları ve sertifikalı orman ürünleri imalatçılarıdır. Sosyal Güvenlik Kurumu (SGK) kayıtlarına göre çalışan sayısı 30 kişiden fazla orta ve büyük ölçekli 10 sertifikalı olmayan orman ürünleri imalatçıları çalışmaya dâhil edilmiştir. Sertifikalı orman ürünleri imalatçıları olarak ise araştırmanın yürütüleceği zamanda bağımsız bir üçüncü taraf sertifikasyon kuruluşu olan FSC tarafindan sertifikasyona tabi tutulmuş orman ürünleri üreten 4 imalatçı alınmıştır. Çalışmanın FSC sertifikalı firmalarla sınırlandırılmasının nedeni, ülkemizde FSC'nin halen önemli ilerleme gösteren sertifikasyon kuruluşu olmasıdır.

\subsection{2. Örnekleme yöntemi}

Batı Akdeniz bölgesindeki çalışan sayısı 30 kişiden fazla orta ve büyük ölçekli sertifikalı olmayan orman ürünleri imalatçlların belirlenmesi için SGK kayıtlarına başvurulmuştur. Araştırmanın amaçları doğrultusunda ikinci hedef kitle olan sertifikalı orman ürünleri imalatçıları için örnekleme yapılmamış ve FSC'nin internet sitesinde (www. fsc.org/en) ilan edilen Bölgedeki tüm imalatçılar çalışmaya dâhil edilmiştir.

\subsubsection{Veri çözümlemeleri ve değerlendirme yöntemleri}

İmalatçı karar vericilerin sertifikasyona tabi olup olmama kararını modellemek için bu çalışmada AHS yani "Analitik Hiyerarşi Süreci" tekniği kullanılmıştır.

AHS tekniği ilk olarak 1968 yılında James H. Myers ve Mark I. Alpert tarafından ortaya atılmış olup (Myers ve Alpert, 1968), 1977 yılında Thomas L. Saaty tarafından bir model olarak geliştirilerek (Saaty, 1977) karar verme problemlerinin çözümünde kullanılan çok kriterli karar verme tekniklerinden birisi haline getirilmiştir. AHS tekniği karmaşık, yapılandırılmamış ve çok kriterli karar verme süreçlerinde karar vermeye yardımcı olan 
bir araçtır. Bu teknik, karar vermede birey veya grubun önceliklerini dikkate alarak nitel (sözel, kalitatif) ve nicel (sayısal, kantitatif) değişkenleri bir arada değerlendirmektedir.

Bir karar verme probleminin AHS tekniği ile çözümlenebilmesi için izlenmesi gereken uygulama adımları aşağıdaki şekilde özetlenebilir (Saaty, 1980, 1990 ve 1994; Kumar ve Ganesh, 1996):

(1) Modelin Kurulmasl ve Problemin Formüle Edilmesi: Karar verme problemini tanımlayacak şekilde karar elemanlarından oluşan bir karar hiyerarşisi kurulur.

(2) Verilerin Toplanması ve İkili Karşılaştırmalar Matrisinin Oluşturulması: Karar elemanları ikili olarak kendi aralarında karşıllaştırılır ve veriler elde edilir. İkili karşılaştırmalar sonucu elde edilen değerler "ikili karşılaştırmalar matrisi" adı verilen matrislere yerleştirilir.

(3) Özdeğer Yöntemi Kullanılmak Suretiyle Karar Elemanlarının Göreli Öncelik Değerlerinin ve Tutarlılık Oranlarının Tahmin Edilmesi: Bunun için matris sütunlarında yer alan değerler toplanarak sütun toplamları elde edilir. Ardından sütunda yer alan her bir değer sütun toplamına bölünerek normalleştirilir. Sonrasında satırda yer alan değerlerin ortalamaları alınarak özvektörler ( $w$ öncelik vektörü) elde edilir. Ardından aşağıdaki formül ile " $T u$ tarlllık Indeksi (TI)" belirlenir;

$$
\mathrm{TI}=\frac{\lambda_{\max }-\mathrm{n}}{\mathrm{n}-1}
$$

Ardından matris boyutuna göre "Rasgele (Tesadüfi) Indeks (RI)" değerleri tespit edilmektedir. Böylece "Tutarlılık Oranı (TO)" aşağıdaki formül yardımıyla hesaplanır;

$$
\mathrm{TO}=\frac{\mathrm{TI}}{\mathrm{R} \dot{\mathrm{I}}}
$$

Bu oran 0,10 (\% 10)'dan küçük olması, elde edilen sonuçların kabul edilebilir sınırlar içinde olduğunu ifade eder.

(4) Karar Alternatiflerinin Genel Öncelik Değerlerinin ve Sıralamasının Elde Edilmesi: Bu son aşamada karar hiyerarşisinin her bir düzeyindeki elemanın öncelik değeri, bunun bağlı olduğu bir üst düzeydeki elemanın öncelik değeri ile ağırlıklandırılır. Sonuçta toplama işlemi en aşağı düzeydeki elemanlar için yapılarak karar alternatiflerinin öncelik değerleri (göreceli bileşik ağırlığı) hesaplanır (Saaty, 1980). Sonuçta AHS tekniğinin son aşaması, karar hiyerarşisinin en aşağı düzeyindeki elemanların (karar alternatiflerinin) en üst düzey- deki genel amaca göre genel öncelik değerlerinin belirlenmesidir.

AHS tekniği ile karmaşık karar verme problemleri hiyerarşik olarak basit bir yapıya kavuşturulmaktadır. AHS tekniğinde katılımcılar, hem kantitatif ve hem de kalitatif faktörleri beraberce dikkate alarak karar alternatiflerini değerlendirebilir ve en uygun karar alternatifinin seçilmesine yönelik karar alabilir. Bu haliyle AHS tekniği; karmaşık karar problemlerinin çözümünde sağladığ1 basitlik, esneklik, kullanım kolaylığg ve rahat yorumlanması ile her türlü kişisel, kurumsal, ulusal vb. problemlere kolaylıkla uygulanabilecek durumda bir tekniktir (Yılmaz, 1999).

Öte yandan bu araştırma birden fazla katılımcıyla gerçekleştirildiği için katılımcıların cevaplarını birleştirme yönünde geometrik ortalama kullanılmıştır (Schmoldt ve ark., 1994). Sonuçta çözümlemelerde bireysel önceliklendirme yerine geometrik ortalama kullanılmıştır. Geometrik ortalama hesabında kullanılan formül aşağıda verilmiştir.

$a_{m n}^{*}=\sqrt[p]{\prod_{k=1}^{p} a_{m n}^{k}}$

Burada,

$a_{m n} *=$ Geometrik ortalama,

$p=$ Katılimcı sayısı,

$a_{m n}=\mathrm{m}$ karar elemanının $\mathrm{n}$ karar elemanına göre göreceli öncelik değeri

Böylece her bir karar elemanına atanan göreceli önem derecesini temsil etmek için $\mathrm{w}_{1}, \mathrm{w}_{2}, \ldots \mathrm{w}_{\mathrm{n}}$ ile gösterilen ve toplamı 1'e eşit olan sayısal ağırlıklar seti hesaplanmıştır.

\subsection{Modelin kurulması ve problemin formüle edilmesi}

AHS'yi karar verme sürecinin modellemesi yönünde kullanmak için kararın bütününü oluşturan kısımlarının parçalara ayrılması ve bir hiyerarşi oluşturulması gerekmektedir. Çalışmanın bu bölümündeki AHS hiyerarşisi üç düzeyden oluşmuştur. Bunlar; "genel amaç" (verilecek kararın bir ifadesi), karar verme sürecinde dikkate alınması gereken "karar kriterleri" ve dikkate alınacak olası "karar alternatifleri"dir.

Daha sonra katılımcılardan, ikili karşılaştırmalar yoluyla modeldeki karar kriterlerini ve alternatiflerini öncelik sırasına koymaları istenmiştir. Ardından katılımcılar öncelik sıralaması işlemini tamamlamış, karar kriterlerinin ve karar alternatiflerinin ağırlıkları hesaplanmış ve tercih edilen alternatif hesaplanan ağırlıklara dayalı olarak ortaya konulmuştur. 


\subsubsection{Başlangıçtaki AHS kriterleri}

AHS modeli geliştirmenin ilk adımını, bir orman ürünü imalatçısının sertifikalı orman ürünleri üretip üretmeme kararını vereceğinde dikkate alacağı en önemli kriterlerin belirlenmesi oluşturmaktadır. $\mathrm{Bu}$ kriterler karar verme modelinin temelini oluşturacak ve katılımcılar tarafından gerçekleştirilecek ilk düzey ikili karşılaştırmalara konu olacaktır. Bir firmanın sertifikalı orman ürünleri üretimini düşündüğünde dikkate alabileceği olası kriterler aşağıdaki şekilde sıralanabilir:

- Mevcut piyasadaki sertifikalı ürün talebinin karşılanması,

- Mevcut piyasada yeni müşterilerin elde edilmesi,

- Yeni piyasalara girerek yeni müşterilerin elde edilmesi,

- Mevcut ürünlerin pazarlamasının ve satışının iyileştirilmesi,

- Rakip firmalarla rekabetçi durumun sürdürülmesi,

- Başarılı firmalarla rekabet edebilme,

- İşletme maliyetinin düşürülmesi,

- Ürün kalitesinin iyileştirilmesi,

- Firmanın kendi süreçlerinin ve uygulamalarının iyileştirilmesi,

- Yerel toplumla ilişkilerin iyileştirilmesi,

- Çevresel sivil toplum kuruluşlarıyla ilişkilerin iyileştirilmesi,

- Kendini geleceğe hazırlaması,

- Firmanın imaj ve itibarının iyileştirilmesi,

- Kâr potansiyelinin arttırılması,

- Mevcut tedarikçiler üzerine etkisi,

- Sanayideki eşdüzey rakiplerin tepkisi,

- Üst yönetimin kişisel kanaati ve idealizmi,

- Sertifikasyonun parasal maliyeti,

- Zaman ve işgücü kaybetmesi,

- Yeni tedarikçiler elde etmesi,

- Yeni piyasalar geliştirmesi,

- Gelecekte olumsuz sonuçların olmasını engellemesi.

\subsubsection{AHS kriterlerinin azaltılması}

Bir sonraki adım, yukarıdaki 22 kriterden oluşan listenin, modele dâhil edilecek 7 kritere düşürülmesidir. Zira AHS tekniği kapsamındaki ikili karşılaştırmaları sağlıklı şekilde yapabilmek için, kriter sayısının (yani ikili karşılaştırmalara konu olacak eleman sayısının) $7 \pm 2$ kadar olması gerekmektedir (Schmoldt ve ark., 1994). 6 kriterli bir AHS modelinde, katılımcılar 15 ayrı kriter karş1laştırması yapmalıdır. Bununla birlikte 7 kriterli bir AHS modelinde, katılımcılar 21 ayrı kriter kar-
Şılaştırması yapmalıdır. Böylece sadece tek bir kriterin ilavesi, katılımcıların çalışmayı tamamlama yönünde harcadıkları zamanı önemli şekilde arttırmaktadır. $\mathrm{Bu}$ nedenle katılımcıların çalışmayı rahatlıkla tamamlamalarına imkân vermek üzere 7 kriterli bir AHS modeli geliştirilmiştir.

Modeldeki 22 kriterin 7'ye düşürülmesinde 'Sıralama (Ranking)" tekniğinden faydalanılmış olup, bu amaçla Batı Akdeniz Ormancılık Araştırma Enstitüsü Müdürlüğü, Antalya Orman Bölge Müdürlüğü ve orman ürünleri sanayindeki 14 uzmanın görüşlerine başvurulmuştur.

Sıralama tekniğinde (Yılmaz, 2005; Y1lmaz ve ark., 2009; Lee, 1995); AHS tekniğinin ikili karşılaştırmalar yaklaşımından farklı olarak, kriterler kendi aralarında ikili olarak karşılaştırılmaz. Bunun yerine kriterlere, göreceli önem derecelerine göre görüş belirtilir ve daha sonra buna göre kriterler sıralanır. Bu sıralama işlemi, AHS tekniğinin ikili karşılaştırmalarındaki 1-9 ölçeğine benzeyen "dokuz dereceli ölçek" vasıtasıyla yapılmaktadır. Bu ölçekte; "l-zayıf oranda önemli", "3-daha az önemli", "5-orta derecede önemli", "7-daha çok önemli" ve "9-aşırl derecede önemli" olarak kabul edilmekte ve " $2,4,6,8$ değerleri" de orta değerler olarak kullanılabilmektedir. Böylece kriterlerin göreceli önem değerleri ya da ağırlıkları her bir kritere verilen sıraya dayalı olarak hesaplanmaktadır.

Örneğin bir $k$ karar vericisi $j$ kriterinin alt kriterine $\mathrm{r}_{\mathrm{jk} 1}, \mathrm{r}_{\mathrm{jk} 2}, \ldots, \mathrm{r}_{\mathrm{jkm}}$ şeklinde bir sıralama verdiği kabul edilsin. Buna göre i alt kriterinin göreceli ağırlık değeri olan $\mathrm{W}_{\mathrm{ji}}$ değeri, aşağıdaki şekilde hesaplanabilir:

$$
\mathrm{W}_{\mathrm{ji}}=\frac{\sum_{\mathrm{k}} \mathrm{r}_{\mathrm{jki}}}{\sum_{\mathrm{i}} \sum_{\mathrm{k}} \mathrm{r}_{\mathrm{jki}}} \quad(\mathrm{i}=1,2, \ldots, \mathrm{m})
$$

Bu işlem sonucunda seçilen 7 karar kriteri aşağıda sıralanmıştır:

1. Mevcut piyasadaki sertifikalı ürün talebinin karşılanması (Talep),

2. Yeni piyasalara girerek yeni müşterilerin elde edilmesi (Yeni Piyasalar),

3. Rakip firmalarla rekabetçi durumun sürdürülmesi (Rekabet),

4. Ürün kalitesinin iyileştirilmesi (Ürün Kalitesi),

5. Firmanın imaj ve itibarının iyileştirilmesi (İmaj),

6. Kâr potansiyelinin arttırılması (Kâr) ve

7. Gelecekte olumsuz sonuçların olmasını engelleme (Gelecek). 


\subsubsection{Tamamlanmış AHS modeli}

AHS modelinde kullanılacak kriter sayısı 7'ye düşürüldükten sonra AHS modelinin hiyerarşik yapısı kurulmuştur. $\mathrm{Bu}$ doğrultuda hiyerarşinin en üst düzeyine genel amaç olan "Sertifikall Orman Ürünleri Üretip Üretmeme Kararının Belirlenme$s i$ " yerleştirilmiştir. Hiyerarşinin ikinci düzeyinde "Karar Kriterleri" yer almıştır. Karar hiyerarşisinin üçüncü ve son düzeyinde ise karar vericinin dikkate alacağ1 "Karar Alternatifleri" bulunmaktadır. AHS modelinin genel amac1 "Sertifikal Orman Ürünleri Üretip Üretmeme Kararının Belirlenmesi" olması nedeniyle, karar alternatifleri "Sadece Sertifikalı Olmayan Orman Ürünü Üretme", "Sadece Sertifikalı Orman Ürünü Üretme" ve "Hem Sertifikall Hem Sertifikalı Olmayan Orman Ürünü Üretme" olmuştur.

\subsection{AHS tekniği verilerinin toplanması}

Sertifikalı ve sertifikalı olmayan imalatçılar için ana veriler, tarafımızdan geliştirilen bir bilgi formu vasıtasıyla toplanmıştır. Firmanın sertifikalı orman ürünü üretip üretmeme kararını verenler her bir firmanın üst yönetimi olması dolayısıyla, bilgi formu her bir firmanın sahibince veya yetkili personelince doldurulmuştur. Bilgi formunu cevaplayanlara 7 AHS karar kriterinin açıklaması yapılmış ve firmalarının sertifikalı orman ürünü üretip üretmeme kararını vermeye çalıştığını varsaymaları istenmiştir. Bilgi formunu cevaplayanlardan karar vermek için gerekli tüm bilgiyi topladıklarını varsaymaları söylenmiştir. Ardından her bir kriteri diğerlerine karşı puanlamaları istenmiş ve sertifikalı orman ürünü üretip üretmeme kararında diğerlerine nazaran ne kadar daha önemli olduğunu belirtmeleri talep edilmiştir.

Ayrıca cevap verenlerden üç olası alternatifi (Sadece Sertifikalı Olmayan Orman Ürünü Üretme, Sadece Sertifikalı Orman Ürünü Üretme, Hem Sertifikalı Hem Sertifikalı Olmayan Orman Ürünü Üretme) birbirlerine göre puanlamaları da istenmiştir. Böylece hazırlanan bilgi formlarında 1-9 ölçek doğrusu kullanılarak, ilgili katılımcılar tarafından karar hiyerarşisinin bir üst düzeyindeki karar elemanlarının her birine göre her bir düzeydeki karar elemanlarının kendi aralarında ikili olarak karşılaştırmaları yapılmıştır. Elde edilen verilere göre, ikili karşılaştırmalar matrisleri elde edilmiştir. Ardından karar hiyerarşisinin farklı düzeylerindeki her bir karar elemanının (karar kriterleri ve karar alternatifleri) göreceli önemleri veya öncelik değerleri belirlenmiştir.

\subsection{Duyarlılık analizleri}

Karar alternatiflerine yönelik tercih önceliği sıra- lamasının, karar kriterlerine ait öncelik değerlerindeki değişimlere karşı duyarlı olup olmadığını ortaya koymak üzere duyarlılık analizleri gerçekleştirilmiştir. Bunun için karar kriterlerine göre karar alternatiflerinin öncelik değerlerindeki değişikliklerin, alternatiflerin orijinal öncelik sıralamasını etkileyip etkilemediği araştırılmıştır.

\section{Bulgular}

Araştırmada imalatçı karar vericilerin sertifikasyona tabi olup olmama kararına nasıl yaklaştıkları incelenmiştir. İmalatçıların sertifikasyona tabi olup olmama kararı, iş düzeyinde stratejik bir karardır. Dolayısıyla firmanın başarısında hayati bir öneme sahiptir. Bu nedenle karar vericilerin sertifikasyon kararına nasıl yaklaştıklarının incelenmesi ve karar vermede onlara bir k1lavuzun sunulması, bu kararla yüz yüze gelen ve ne yapacağını bilemeyen bireylere önemli katkı sağlayacaktır. Bu çalışma, karar vericilere kararlarına bir çözüm üretmede kullanabilecekleri bir araç vermek suretiyle kılavuz vazifesi görecektir.

\subsection{Sertifikalı imalatçıların sertifikalı ürün üretme kararı}

\subsubsection{Sertifikalı imalatçıların karar kriterlerine yönelik öncelikleri}

Çalışmaya katılan sertifikalı imalatçıların 7 karar kriterine yönelik olarak yaptıkları ikili karşılaştırmalardan elde edilen verilerin geometrik ortalamalarına dayalı olarak hesaplanan öncelik değerleri ve öncelik sıralaması Tablo 1'de verilmiştir.

Tablo 1'de görüleceği üzere sertifikalı imalatçıların en yüksek önemden en düşük önemde gördüklerine doğru karar kriterlerinin öncelik sıralamasının imaj $(0,293)$, yeni piyasalar $(0,151)$, kâr $(0,131)$, talep $(0,124)$, ürün kalitesi $(0,119)$, rekabet $(0,116)$ ve gelecek $(0,067)$ şeklinde olduğu anlaşılmaktadır.

Tablo 1. Sertifikalı imalatçıların karar kriterlerine yönelik öncelik değerleri ve sıralamaları

Table 1. The priority values and ranking of the decision criteria in the opinion of representatives of the certified manufacturers

\begin{tabular}{lcc}
\hline Karar kriterleri & Öncelik değeri & Siralama \\
\hline Talep & 0,124 & 4 \\
Yeni Piyasalar & 0,151 & 2 \\
Rekabet & 0,116 & 6 \\
Ürün Kalitesi & 0,119 & 5 \\
İmaj & 0,293 & 1 \\
Kâr & 0,131 & 3 \\
Gelecek & 0,067 & 7 \\
\hline
\end{tabular}




\subsubsection{Sertifikalı imalatçıların her bir karar kriterine göre karar alternatiflerine yönelik öncelikleri}

Sertifikalı imalatçıların her biri tarafından talep, yeni piyasalar, rekabet, ürün kalitesi, imaj, kâr ve gelecek karar kriterlerinin her birine göre sadece sertifikalı olmayan orman ürünü üretme, sadece sertifikalı orman ürünü üretme ve hem sertifikalı hem sertifikalı olmayan orman ürünü üretme karar alternatiflerine yönelik olarak yapılan ikili karşılaştırmalardan elde edilen verilerin geometrik ortalamaları hesaplanarak Tablo 2'de sunulmuş olan öncelik değerleri ve öncelik sıralaması elde edilmiştir.

Tablo 2. Sertifikalı imalatçılar açısından her bir karar kriterine göre karar alternatiflerinin ortalama öncelik değerleri ve sıralamaları

Table 2. The mean priority values and ranking of the decision alternatives with respect to each decision criterion, determined by certified manufacturers

\begin{tabular}{lcccccc}
\hline \multirow{2}{*}{ Karar Kriterleri } & \multicolumn{2}{c}{$\begin{array}{c}\text { Karar Alternatifleri } \\
\text { Olmayan }\end{array}$} & \multicolumn{2}{c}{ Sadece Sertifikalı } & \multicolumn{2}{c}{$\begin{array}{c}\text { Hem Sertifikalı Hem } \\
\text { Sertifikalı Olmayan }\end{array}$} \\
\cline { 2 - 7 } & Öncelik & Siralama & Öncelik & Siralama & Öncelik & Siralama \\
\hline Talep & 0,118 & 3 & 0,622 & 1 & 0,259 & 2 \\
Yeni Piyasalar & 0,139 & 3 & 0,588 & 1 & 0,272 & 2 \\
Rekabet & 0,192 & 3 & 0,365 & 2 & 0,443 & 1 \\
Ürün Kalitesi & 0,142 & 3 & 0,561 & 1 & 0,297 & 2 \\
İmaj & 0,110 & 3 & 0,580 & 1 & 0,310 & 2 \\
Kâr & 0,189 & 3 & 0,503 & 1 & 0,309 & 2 \\
Gelecek & 0,192 & 3 & 0,387 & 2 & 0,420 & 1 \\
\hline
\end{tabular}

Buna göre sadece sertifikalı orman ürünü üretme karar alternatifi talep $(0,622)$, yeni piyasalar $(0,588)$, ürün kalitesi $(0,561)$, imaj $(0,580)$ ve kâr $(0,503)$ karar kriterleri için en uygun karar alternatifidir. Buna karşın hem sertifikalı hem sertifikalı olmayan orman ürünü üretme karar alternatifi, diğer karar kriterleri olan rekabet $(0,443)$ ve gelecek $(0,420)$ karar kriterleri için en fazla tercih edilen karar alternatifi olmuştur. Sadece sertifikalı olmayan orman ürünü üretme karar alternatifi ise karar kriterlerinin tamamı için en düşük önceliği almıştır.

\subsubsection{Sertifikalı imalatçılara yönelik karar alternatiflerinin genel öncelik değerlerinin ve sıralamasının elde edilmesi}

AHS tekniği yardımıyla, çalıșmaya katılan sertifikalı imalatçıların hükümlerine dayalı olarak sertifikalı ürün üretilip üretilmeme kararını belirlemek üzere, AHS karar hiyerarşisinin en alt düzeyindeki karar alternatiflerinin hiyerarşinin en üst düzeyindeki genel amaca göre genel öncelik değerlerinin belirlenmesi işlemi yerine getirilmiştir. Bu doğrultuda karar hiyerarşisinin her bir düzeyindeki öncelik değerleri matrislerini kombine eden bir sayısal hesaplama yürütülmüştür. Bir başka ifadeyle karar hiyerarşisinin her bir düzeyindeki karar elemanının öncelik değeri, bunun bağlı olduğu bir üst düzeydeki elemanın öncelik değeri ile ağırlıklandırılmıştır. Ardından toplama işlemi karar hiyerarşisinin en alt düzeyindeki elemanlar için yapılarak, her bir karar alternatifinin öncelik değerine ulassılmıștır.

Sonuçta sertifikalı imalatçılara yönelik sadece sertifikalı olmayan orman ürünü üretme, sadece sertifikalı orman ürünü üretme ve hem sertifikalı hem sertifikalı olmayan orman ürünü üretme karar alternatiflerinin her birisi için AHS tekniği kullanılarak Tablo 3'de verilen genel öncelik değerlerine ve öncelik sıralamasına ulaşılmıştır.

Tablo 3. Sertifikalı imalatçılar açısından sertifikalı orman ürünü üretip üretmeme problemindeki karar alternatiflerinin öncelik değerleri ve sıralaması

Table 3 . The priority values and ranking of the decision alternatives in the problem of whether or not production of certified forest product, determined by certified manufacturers

\begin{tabular}{lcc}
\hline Karar alternatifleri & $\begin{array}{c}\text { Öncelik } \\
\text { değeri }\end{array}$ & $\begin{array}{c}\text { Öncelik } \\
\text { sıras1 }\end{array}$ \\
\hline $\begin{array}{l}\text { Sadece Sertifikalı Olmayan } \\
\text { Orman Ürünü Üretme }\end{array}$ & 0,145 & 3 \\
$\begin{array}{l}\text { Sadece Sertifikalı } \\
\text { Orman Ürünü Üretme }\end{array}$ & 0,536 & 1 \\
$\begin{array}{l}\text { Hem Sertifikalı Hem } \\
\text { Sertifikalı Olmayan Orman } \\
\text { Ürünü Üretme }\end{array}$ & 0,319 & 2 \\
\hline
\end{tabular}

Buna göre AHS tekniği çözümlemeleri, sertifikalı imalatçılar tarafından en fazla tercih edilen karar alternatifinin 0,536 öncelik değeri ile sadece ser- 
tifikalı orman ürünü üretme olduğunu ortaya koymuştur. İkinci en fazla tercih edilen karar alternatifi 0,319 öncelik değerine sahip hem sertifikalı hem sertifikalı olmayan orman ürünü üretmedir. Üçüncü ve en az tercih edilen karar alternatifi ise 0,145 öncelik değeri ile sadece sertifikalı olmayan orman ürünü üretme alternatifinin olduğu anlaşılmıştır.

\subsection{Sertifikalı olmayan imalatçıların sertifikalı ürün üretme kararı}

\subsubsection{Sertifikalı olmayan imalatçıların karar kriterlerine yönelik öncelikleri}

Çalışmaya dahil olan sertifikalı olmayan imalatçıların 7 karar kriterine yönelik yaptıkları ikili karşılaştırmalar ve bu verilerin geometrik ortalamaları hesaplanarak elde edilmiş olan öncelik değerleri ve öncelik sıralaması Tablo 4'te sunulmuştur.

Tablo 4. Sertifikalı olmayan imalatçıların karar kriterlerine yönelik öncelik değerleri ve sıralamaları Table 4 . The priority values and ranking of the decision criteria in the opinion of representatives of the noncertified manufacturers

\begin{tabular}{lcc}
\hline Karar kriterleri & Öncelik değeri & Siralama \\
\hline Talep & 0,053 & 7 \\
Yeni Piyasalar & 0,084 & 6 \\
Rekabet & 0,129 & 4 \\
Ürün Kalitesi & 0,139 & 2 \\
İmaj & 0,117 & 5 \\
Kâr & 0,345 & 1 \\
Gelecek & 0,133 & 3 \\
\hline
\end{tabular}

Sertifikalı olmayan imalatçılar tarafından karar kriterlerine verilmiş olan öncelik değerleri ve öncelik sıralaması incelendiğinde, en yüksek öncelik değerine sahip karar kriterinin kâr $(0,345)$ kriteri olduğu, bunu sırasıyla ürün kalitesi $(0,139)$, gelecek $(0,133)$, rekabet $(0,129)$, imaj $(0,117)$ ve yeni piyasalar $(0,084)$ kriterlerinin izlediği ve en düşük öncelik değerine sahip karar kriterinin ise talep $(0,053)$ kriterinin olduğu görülmektedir.

\subsubsection{Sertifikalı olmayan imalatçıların her bir karar kriterine göre karar alternatiflerine yönelik öncelikleri}

Sertifikalı olmayan imalatçıların her birisi tarafından karar kriterlerinin her birisine göre karar alternatiflerine yönelik olarak yapılan ikili karşılaştırmalardan elde edilen verilerin geometrik ortalamaları hesaplanarak Tablo 5'te verilmiş olan öncelik değerlerine ve öncelik sıralamasına ulaşılmıştır.

Buna göre sadece sertifikalı orman ürünü üretme karar alternatifi rekabet $(0,430)$ ve kâr $(0,384)$ karar kriterleri için en uygun karar alternatifidir. Buna karşın hem sertifikalı hem sertifikalı olmayan orman ürünü üretme karar alternatifi, diğer karar kriterleri olan talep $(0,505)$, yeni piyasalar $(0,505)$, ürün kalitesi $(0,456)$, imaj $(0,468)$ ve gelecek $(0,408)$ karar kriterleri için en fazla tercih edilen karar alternatifleridir. Sadece sertifikalı olmayan orman ürünü üretme karar alternatifi ise karar kriterlerinin tamamı için en düşük önceliğe sahip olmuştur.

Tablo 5. Sertifikalı olmayan imalatçılar açısından her bir karar kriterine göre karar alternatiflerinin ortalama öncelik değerleri ve sıralamaları

Table 5. The mean priority values and ranking of the decision alternatives with respect to each decision criterion, determined by non-certified manufacturers

\begin{tabular}{lcccccc}
\hline \multirow{2}{*}{ Karar Kriterleri } & \multicolumn{2}{c}{$\begin{array}{c}\text { Karar Alternatifleri } \\
\text { Olmayan }\end{array}$} & \multicolumn{2}{c}{ Sadece Sertifikalı } & \multicolumn{2}{c}{$\begin{array}{c}\text { Hem Sertifikalı Hem } \\
\text { Sertifikali Olmayan }\end{array}$} \\
\cline { 2 - 7 } & Öncelik & Siralama & Öncelik & Siralama & Öncelik & Siralama \\
\cline { 2 - 7 } Talep & 0,182 & 3 & 0,314 & 2 & 0,505 & 1 \\
Yeni Piyasalar & 0,172 & 3 & 0,323 & 2 & 0,505 & 1 \\
Rekabet & 0,201 & 3 & 0,430 & 1 & 0,369 & 2 \\
Ürün Kalitesi & 0,211 & 3 & 0,333 & 2 & 0,456 & 1 \\
İmaj & 0,185 & 3 & 0,347 & 2 & 0,468 & 1 \\
Kâr & 0,307 & 3 & 0,384 & 1 & 0,309 & 2 \\
Gelecek & 0,222 & 3 & 0,370 & 2 & 0,408 & 1 \\
\hline
\end{tabular}

\subsubsection{Sertifikalı olmayan imalatçılara} yönelik karar alternatiflerinin genel öncelik değerlerinin ve sıralamasının elde edilmesi

AHS tekniği yardımıyla çalışmaya katılan sertifikalı olmayan imalatçıların hükümlerine dayalı olarak sertifikalı ürün üretilip üretilmeme kararını belirlemek üzere, sertifikalı imalatçılarda uygulanan hesaplama süreci tekrar edilmiştir. Sonuçta sertifikalı olmayan imalatçılara yönelik sadece sertifikalı olmayan orman ürünü üretme, sadece sertifikalı orman ürünü üretme ve hem sertifikalı 
hem sertifikalı olmayan orman ürünü üretme karar alternatiflerinin her birisi için AHS tekniği kullanılarak Tablo 6'da sunulan genel öncelik değerlerine ve öncelik sıralamasına ulaşılmıştır.

Tablo 6. Sertifikalı olmayan imalatçılar açısından sertifikalı orman ürünü üretip üretmeme problemindeki karar alternatiflerinin öncelik değerleri ve sıralaması Table 6 . The priority values and ranking of the decision alternatives in the problem of whether or not production of certified forest product, determined by non-certified manufacturers

\begin{tabular}{lcc}
\hline Karar alternatifleri & $\begin{array}{c}\text { Öncelik } \\
\text { değeri }\end{array}$ & $\begin{array}{c}\text { Öncelik } \\
\text { sırası }\end{array}$ \\
\hline $\begin{array}{l}\text { Sadece Sertifikalı Olmayan } \\
\text { Orman Ürünü Üretme }\end{array}$ & 0,236 & 3 \\
$\begin{array}{l}\text { Sadece Sertifikalı Orman } \\
\text { Ürünü Üretme }\end{array}$ & 0,368 & 2 \\
$\begin{array}{l}\text { Hem Sertifikalı Hem } \\
\text { Sertifikalı Olmayan Orman } \\
\text { Ürünü Üretme }\end{array}$ & 0,396 & 1 \\
\hline
\end{tabular}

Buna göre AHS tekniği hesaplamaları, sertifikalı olmayan imalatçılar tarafindan en fazla tercih edilen karar alternatifinin 0,396 öncelik değeri ile hem sertifikalı, hem sertifikalı olmayan orman ürünü üretme olduğunu göstermiştir. İkinci en fazla tercih edilen karar alternatifi 0,368 öncelik değerine sahip sadece sertifikalı orman ürünü üretmedir. Üçüncü ve en az tercih edilen karar alternatifi ise 0,236 öncelik değeri ile sadece sertifikalı olmayan orman ürünü üretme alternatifinin olduğu ortaya çıkmıştır.

\subsection{Duyarlılık analizleri}

\subsubsection{Sertifikalı imalatçılar için karar kriterlerinin öncelik değerlerindeki değişikliğe dayalı duyarlılık analizleri}

Bu çalışmadaki AHS tekniği karar verme modelinin karar kriterleri olan talep, yeni piyasalar, rekabet, ürün kalitesi, imaj, kâr ve gelecek kriterlerine ait öncelik değerlerinde yapılan değişikliklerin, sertifikalı imalatçılar için olmak üzere, orijinal öncelik sıralamasına etkileri araştırılmıştır.

Bu doğrultuda öncelikle her bir karar kriterine eşit öncelik değeri $(1 / 7=0,143)$ atanarak, AHS tekniği hesaplamaları yeniden gerçekleştirilmiştir. Sonuçta elde edilen karar alternatiflerinin öncelik değerleri ve öncelik sıralaması Tablo 7'de verilmiştir. Buna göre karar kriterlerine eşit öncelik değeri verilmesi durumunda, her ne kadar öncelik değerleri değişse de karar alternatiflerine yönelik öncelik s1ralaması değişmemektedir.

Bir diğer incelemede, her bir karar kriterinin mo- del dışı bırakılması (yani 0,000 öncelik değeri verilmesi) ve geri kalan karar kriterlerine eşit (1/6 = $0,167)$ öncelik değeri verilmesi durumunda sonuçlardaki değişim konusu ele alınmıştır. Bu koşullar altında yinelenen AHS tekniği sonuçları Tablo 8'de gösterilmiştir. Elde edilen hesaplama sonuçları karar kriterlerinde bu şekilde yapılan öncelik değerleri değişikliğinin, her ne kadar karar alternatiflerine ait orijinal öncelik değerlerini değiştirse de, orijinal öncelik sıralamasını değiştirmediğini ortaya koymuştur.

Tablo 7. Duyarlılık analizi: Sertifikalı imalatçılar açısından karar kriterlerine eşit öncelik değerleri $(1 / 7=0,143)$ verilmesi durumunda karar alternatiflerinin öncelik değerleri ve siralamaları

Table 7. Sensitivity analysis: the priority values and ranking of the decision alternatives, the weights of decision criteria are assumed to be equal, i.e. $(1 / 7=0,143)$, according to certified manufacturers

\begin{tabular}{lcc}
\hline Karar alternatifleri & $\begin{array}{c}\text { Öncelik } \\
\text { değeri }\end{array}$ & $\begin{array}{c}\text { Öncelik } \\
\text { siras1 }\end{array}$ \\
\hline $\begin{array}{l}\text { Sadece Sertifikalı Olmayan } \\
\text { Orman Ürünü Üretme }\end{array}$ & 0,155 & 3 \\
$\begin{array}{l}\text { Sadece Sertifikalı Orman } \\
\text { Ürünü Üretme }\end{array}$ & 0,516 & 1 \\
$\begin{array}{l}\text { Hem Sertifikalı Hem } \\
\text { Sertifikalı Olmayan Orman } \\
\text { Ürünü Üretme }\end{array}$ & 0,330 & 2 \\
\hline
\end{tabular}

Ardından AHS tekniği çözümlemeleri, tek kriterli karar verme koşulları altında tekrar edilmiştir. $\mathrm{Bu}$ amaçla her defasında bir karar kriterine 1,000 ve geri kalanlara 0,000 öncelik değerleri verilerek hesaplamalar yapılmıştır. Ulaşılan sonuçlar Tablo 9'da sunulmuştur. Buna göre Rekabet ve Gelecek kriterinin modele dâhil edildiği durumda, karar alternatiflerinin orijinal öncelik değeri ve sıralaması değişmektedir. Diğer karar kriterleri için tek kriterli çözümlemeler gerçekleştirildiğinde ise alternatiflerin öncelik sıralaması bu değişikliklerden etkilenmemektedir.

\subsubsection{Sertifikalı olmayan imalatçılar için karar kriterlerinin öncelik değerlerindeki değişikliğe dayalı duyarlılık analizleri}

Sertifikalı olmayan imalatçılar için olmak üzere, bu çalışmadaki AHS modelinin karar kriterlerine ait öncelik değerlerinde yapılan değişikliklerin orijinal öncelik sıralamasına etkileri incelenmiştir.

Bunun için öncelikle her bir karar kriterine eşit öncelik değeri $(1 / 7=0,143)$ verilmiş ve AHS tekniği çözümlemeleri tekrar edilmiştir. Elde edilen sonuçlar Tablo 10'da sunulmuştur. 
Tablo 8. Duyarlılık analizi: Sertifikalı imalatçılar açısından karar kriterlerine $(0,000-0,167)$ öncelik değerleri verilmesi durumunda karar alternatiflerinin öncelik değerleri ve sıralamaları

Table 8. Sensitivity analysis: Priorities and ranking of the decision alternatives. While the weight of one of the decision criteria is assumed to be 0,000 , the weights of the others are assumed to be equal, i.e. $(1 / 6=0,167)$, according to certified manufacturers

\begin{tabular}{|c|c|c|c|c|c|c|c|c|c|c|c|c|c|c|}
\hline \multirow{3}{*}{ Karar alternatifleri } & \multicolumn{14}{|c|}{0,000 öncelik değerine sahip karar kriterleri (Diğerlerinin öncelik değerleri=1/6=0,167) } \\
\hline & \multicolumn{2}{|c|}{ Talep } & \multicolumn{2}{|c|}{$\begin{array}{c}\text { Yeni } \\
\text { Piyasalar }\end{array}$} & \multicolumn{2}{|c|}{ Rekabet } & \multicolumn{2}{|c|}{$\begin{array}{c}\text { Ürün } \\
\text { Kalitesi }\end{array}$} & \multicolumn{2}{|c|}{ İmaj } & \multicolumn{2}{|c|}{ Kâr } & \multicolumn{2}{|c|}{ Gelecek } \\
\hline & Ön. & Sir. & Ön. & Sira & Ön. & Sira & Ön. & Sira & Ön. & Sira & Ön. & Sira & Ön. & Sira \\
\hline $\begin{array}{l}\text { Sadece Sertifikalı Olmayan } \\
\text { Orman Ürünü Üretme }\end{array}$ & 0,161 & 3 & 0,158 & 3 & 0,149 & 3 & 0,157 & 3 & 0,163 & 3 & 0,149 & 3 & 0,149 & 3 \\
\hline $\begin{array}{l}\text { Sadece Sertifikalı Orman } \\
\text { Ürünü Üretme }\end{array}$ & 0,498 & 1 & 0,504 & 1 & 0,541 & 1 & 0,509 & 1 & 0,505 & 1 & 0,518 & 1 & 0,537 & 1 \\
\hline $\begin{array}{l}\text { Hem Sertifikalı Hem } \\
\text { Sertifikalı Olmayan Orman } \\
\text { Ürünü Üretme }\end{array}$ & 0,343 & 2 & 0,340 & 2 & 0,312 & 2 & 0,336 & 2 & 0,334 & 2 & 0,334 & 2 & 0,316 & 2 \\
\hline
\end{tabular}

Tablo 9. Duyarlılık analizi: Sertifikalı imalatçılar açısından karar kriterlerine $(1,000-0,000)$ öncelik değerleri verilmesi durumunda karar alternatiflerinin öncelik değerleri ve sıralamaları

Table 9. Sensitivity analysis: The priority values and ranking of the decision alternatives. While the weight of one of the decision criteria is assumed to be 1,000 , the weights of the others are assumed to be 0,000 , according to certified manufacturers

\begin{tabular}{|c|c|c|c|c|c|c|c|c|c|c|c|c|c|c|}
\hline \multirow{3}{*}{ Karar alternatifleri } & \multicolumn{14}{|c|}{1,000 öncelik değerine sahip karar kriterleri (Diğerlerinin öncelik değerleri $=0,000$ ) } \\
\hline & \multicolumn{2}{|c|}{ Talep } & \multicolumn{2}{|c|}{$\begin{array}{c}\text { Yeni } \\
\text { Piyasalar }\end{array}$} & \multicolumn{2}{|c|}{ Rekabet } & \multicolumn{2}{|c|}{$\begin{array}{c}\text { Ürün } \\
\text { Kalitesi }\end{array}$} & \multicolumn{2}{|c|}{ İmaj } & \multicolumn{2}{|c|}{ Kâr } & \multicolumn{2}{|c|}{ Gelecek } \\
\hline & Ön. & Sira & Ön. & Sira & Ön. & Sira & Ön. & Sira & Ön. & Sira & Ön. & Sira & Ön. & Sira \\
\hline $\begin{array}{l}\text { Sadece Sertifikalı } \\
\text { Olmayan Orman Ürünü } \\
\text { Üretme }\end{array}$ & 0,118 & 3 & 0,139 & 3 & 0,192 & 3 & 0,142 & 3 & 0,110 & 3 & 0,189 & 3 & 0,192 & 3 \\
\hline $\begin{array}{l}\text { Sadece Sertifikalı } \\
\text { Orman Ürünü Üretme }\end{array}$ & 0,622 & 1 & 0,588 & 1 & 0,365 & 2 & 0,561 & 1 & 0,580 & 1 & 0,503 & 1 & 0,387 & 2 \\
\hline $\begin{array}{l}\text { Hem Sertifikalı Hem } \\
\text { Sertifikalı Olmayan } \\
\text { Orman Ürünü Üretme }\end{array}$ & 0,259 & 2 & 0,272 & 2 & 0,443 & 1 & 0,297 & 2 & 0,310 & 2 & 0,309 & 2 & 0,420 & 1 \\
\hline
\end{tabular}

Tablo 10. Duyarlılık analizi: Sertifikalı olmayan imalatçılar açısından karar kriterlerine eşit öncelik değerleri $(1 / 7=0,143)$ verilmesi durumunda karar alternatiflerinin öncelik değerleri ve sıralamaları Table 10. Sensitivity analysis: the priority values and ranking of the decision alternatives, the weights of decision criteria are assumed to be equal, i.e.( $1 / 7=0,143$ ), according to non-certified manufacturers

\begin{tabular}{lcc}
\hline Karar alternatifleri & $\begin{array}{c}\text { Öncelik } \\
\text { değeri }\end{array}$ & $\begin{array}{c}\text { Öncelik } \\
\text { sırası }\end{array}$ \\
\hline $\begin{array}{l}\text { Sadece Sertifikalı Olmayan } \\
\text { Orman Ürünü Üretme }\end{array}$ & 0,212 & 3 \\
$\begin{array}{l}\text { Sadece Sertifikalı Orman } \\
\text { Ürünü Üretme }\end{array}$ & 0,357 & 2 \\
$\begin{array}{l}\text { Hem Sertifikalı Hem } \\
\text { Sertifikalı Olmayan Orman } \\
\text { Ürünü Üretme }\end{array}$ & 0,432 & 1 \\
\hline
\end{tabular}

Buna göre karar kriterlerine eşit öncelik değeri atanması durumunda, her ne kadar öncelik değer- leri değişse de karar alternatiflerinin öncelik sıralaması aynı kalmaktadır.

Diğer yandan her bir karar kriterinin model diş1 bırakılması (yani 0,000 öncelik değeri verilmesi) ve diğer karar kriterlerine eşit $(1 / 6=0,167)$ öncelik değeri atanması halinde sonuçlarda değişim olup olmadığı incelenmiştir. Bu şekilde yürütülen AHS tekniğinin sonuçları Tablo 11'de verilmiştir. Elde edilen sonuçlar, karar kriterlerinde bu şekilde yapılan öncelik değerleri değişikliğinin, her ne kadar karar alternatiflerinin orijinal öncelik değerlerini değiştirse de orijinal öncelik sıralamasını değiştirmediğini göstermektedir.

Sonrasında AHS tekniğine yönelik çözümlemeler, tek kriterli karar verme koşullarında ele alınmıştır. Bu doğrultuda her seferinde bir karar kriterine 1,000 ve diğerlerine 0,000 öncelik değerleri verilerek hesaplamalar gerçekleştirilmiştir. Elde edilen sonuçlar Tablo 12'de verilmiştir. Buna göre Rekabet ve Kâr kriterlerinin karar verme modeline dâhil 
edildiği durumlarda karar alternatiflerinin orijinal öncelik değeri ve sıralaması değişmektedir. Diğer karar kriterleri için tek kriterli çözümlemeler yapıldığında ise karar alternatiflerinin öncelik sıralaması bu değişikliklerden etkilenmemektedir.

\section{Tartışma ve Sonuç}

Araştırmada, imalatçı karar vericilerin sertifikasyona tabi olup olmama kararına nasıl yaklaştıkları incelenmiştir. İmalatçıların sertifikasyona tabi olup olmama kararı, iş düzeyinde stratejik bir karardır. Dolayısıyla firmanın başarısında hayati öneme sahiptir. Bu nedenle karar vericilerin sertifikasyon kararına nasıl yaklaştıklarının incelenmesi ve karar vermede onlara bir k1lavuzun sunulması, bu kararla yüz yüze gelen ve ne yapacağını bilemeyen bireylere önemli katkı sağlayacaktır. $\mathrm{Bu}$ çalışma, karar vericilere kararlarına bir çözüm üretmede kullanabilecekleri bir araç vermek suretiyle kılavuz vazifesi görecektir. Bu kararı modellemek için "Analitik Hiyerarşi Süreci (AHS)" tekniği kullanılmıştır. AHS tekniğini kullanmanın faydası, kararı önemli elemanlara ayırma ve bu elemanların ilişkisini matematiksel olarak tanımlama yönünde araştırmacılara imkan tanımasıdır.

AHS modeli, sertifikalı imalatçıların sadece sertifikalı orman ürünleri üretmesi gerektiğini ve sertifikalı olmayan imalatçıların her iki orman ürünü tipini üretmesi gerektiğini ortaya koymuştur.

Modelleme sürecinde ilk adım olarak, modelde kullanılacak karar kriterleri listesini geliştirmek için uzman görüşlerine başvurmaktır. Bu süreç modelde kullanılacak 7 karar kriterinin seçimi ile sonuçlanmıştır. Bu kriterler; talep, yeni piyasalar, rekabet, ürün kalitesi, imaj, kâr ve gelecektir.

Öte yandan imalatçıların 7 karar kriterine yönelik tercihleri itibariyle farklılıklar bulunduğu tespit edilmiştir. Sertifikalı imalatçılar imaj kriterini yedi kriterin en önemlisi olarak puanlamıştır. Bununla birlikte sertifikalı olmayan imalatçılar; kâr,

Tablo 11. Duyarlılık analizi: Sertifikalı olmayan imalatçılar açısından karar kriterlerine $(0,000-0,167)$ öncelik değerleri verilmesi durumunda karar alternatiflerinin öncelik değerleri ve siralamaları

Table 11. Sensitivity analysis: Priorities and ranking of the decision alternatives. While the weight of one of the decision criteria is assumed to be 0,000 , the weights of the others are assumed to be equal, i.e. $(1 / 6=0,167)$, according to non-certified manufacturers

\begin{tabular}{|c|c|c|c|c|c|c|c|c|c|c|c|c|c|c|}
\hline \multirow{3}{*}{ Karar alternatifleri } & \multicolumn{14}{|c|}{0,000 öncelik değerine sahip karar kriterleri (Diğerlerinin öncelik değerleri=1/6=0,167) } \\
\hline & \multicolumn{2}{|c|}{ Talep } & \multicolumn{2}{|c|}{$\begin{array}{c}\text { Yeni } \\
\text { Piyasalar }\end{array}$} & \multicolumn{2}{|c|}{ Rekabet } & \multicolumn{2}{|c|}{$\begin{array}{c}\text { Ürün } \\
\text { Kalitesi }\end{array}$} & \multicolumn{2}{|c|}{ İmaj } & \multicolumn{2}{|c|}{ Kâr } & \multicolumn{2}{|c|}{ Gelecek } \\
\hline & Ön. & Sira & Ön. & Sira & Ön. & Sira & Ön. & Sira & Ön. & Sira & Ön. & Sira & Ön. & Sira \\
\hline $\begin{array}{l}\text { Sadece Sertifikalı } \\
\text { Olmayan Orman Ürünü } \\
\text { Üretme }\end{array}$ & 0,217 & 3 & 0,218 & 3 & 0,214 & 3 & 0,212 & 3 & 0,216 & 3 & 0,196 & 3 & 0,210 & 3 \\
\hline $\begin{array}{l}\text { Sadece Sertifikalı } \\
\text { Orman Ürünü Üretme }\end{array}$ & 0,365 & 2 & 0,364 & 2 & 0,346 & 2 & 0,362 & 2 & 0,359 & 2 & 0,353 & 2 & 0,356 & 2 \\
\hline $\begin{array}{l}\text { Hem Sertifikalı Hem } \\
\text { Sertifikalı Olmayan Orman } \\
\text { Ürünü Üretme }\end{array}$ & 0,420 & 1 & 0,420 & 1 & 0,443 & 1 & 0,428 & 1 & 0,426 & 1 & 0,453 & 1 & 0,436 & 1 \\
\hline
\end{tabular}

Tablo 12. Duyarlılık analizi: Sertifikalı olmayan imalatçılar açısından karar kriterlerine $(1,000-0,000)$ öncelik değerleri verilmesi durumunda karar alternatiflerinin öncelik değerleri ve sıralamaları

Table 12. Sensitivity analysis: the priority values and ranking of the decision alternatives. While the weight of one of the decision criteria is assumed to be 1,000 , the weights of the others are assumed to be 0,000 , according to noncertified manufacturers

\begin{tabular}{|c|c|c|c|c|c|c|c|c|c|c|c|c|c|c|}
\hline \multirow{3}{*}{ Karar alternatifleri } & \multicolumn{14}{|c|}{1,000 öncelik değerine sahip karar kriterleri (Diğerlerinin öncelik değerleri $=0,000$ ) } \\
\hline & \multicolumn{2}{|c|}{ Talep } & \multicolumn{2}{|c|}{$\begin{array}{c}\text { Yeni } \\
\text { Piyasalar }\end{array}$} & \multicolumn{2}{|c|}{ Rekabet } & \multicolumn{2}{|c|}{$\begin{array}{c}\text { Ürün } \\
\text { Kalitesi }\end{array}$} & \multicolumn{2}{|c|}{ İmaj } & \multicolumn{2}{|c|}{ Kâr } & \multicolumn{2}{|c|}{ Gelecek } \\
\hline & Ön. & Sira & Ön. & Sira & Ön. & Sira & Ön. & Sira & Ön. & Sira & Ön. & Sira & Ön. & Sira \\
\hline $\begin{array}{l}\text { Sadece Sertifikalı Olmayan } \\
\text { Orman Ürünü Üretme }\end{array}$ & 0,182 & 3 & 0,172 & 3 & 0,201 & 3 & 0,211 & 3 & 0,185 & 3 & 0,307 & 3 & 0,222 & 3 \\
\hline $\begin{array}{l}\text { Sadece Sertifikalı Orman } \\
\text { Ürünü Üretme }\end{array}$ & 0,314 & 2 & 0,323 & 2 & 0,430 & 1 & 0,333 & 2 & 0,347 & 2 & 0,384 & 1 & 0,370 & 2 \\
\hline $\begin{array}{l}\text { Hem Sertifikalı Hem } \\
\text { Sertifikalı Olmayan Orman } \\
\text { Ürünü Üretme }\end{array}$ & 0,505 & 1 & 0,505 & 1 & 0,369 & 2 & 0,456 & 1 & 0,468 & 1 & 0,309 & 2 & 0,408 & 1 \\
\hline
\end{tabular}


ürün kalitesi ve gelecek kriterlerini yüksek önemde puanlamış, buna karşın imaj, yeni piyasalar ve talep kriterlerine daha az önem vermiştir. Bu durum sertifikalı olmayan imalatçıların sertifikasyon konusundaki kararlarını büyük oranda yeni ürünün kâr potansiyeline dayalı olarak verdiğini göstermektedir. Bununla birlikte sertifikalı imalatçılar kararlarını bir kriterler kombinasyonunu dikkate alarak vermektedir. Bu kapsamdaki kombinasyona şunlar dâhildir; imaj, yeni piyasalar ve kâr.

Sertifikalı olmayan imalatçılar için hesaplanan AHS modeli çıktısı, hem sertifikalı, hem sertifikalı olmayan orman ürünü üretmedir. Bununla birlikte sertifikalı imalatçılar için AHS model çıktısı daha ilginçtir. AHS modeli bu imalatçıların sadece sertifikalı orman ürünü üretmesi gerektiğini ortaya koymuştur. Ancak bu imalatçıların hiçbirisi henüz sadece sertifikalı orman ürünleri üretmemektedir. Bu imalatçıların tamamı hem sertifikalı, hem de sertifikalı olmayan orman ürünü üretmektedir.

Sertifikalı olma kararı güç bir karardır ve bir firmanın başarısında önemli bir etkiye sahip olabilir. $\mathrm{Bu}$ nedenle karar vericilere bu kararı vereceği zaman yardımcı olmaya ihtiyaç bulunmaktadır. $\mathrm{Bu}$ çalışmada geliştirilen AHS tekniği modeli bu yardımı sağlayabilir. Karar vericiler bu modele kendi hükümlerini girebilir ve karar verme süreçlerinin bir aracı olarak hesaplanan çıktıyı kullanabilir.

Teşekkür: Bu makale, T.C. Tarım ve Orman Bakanlığı, Batı Akdeniz Ormancılık Araştırma Enstitüsü Müdürlüğünce "Sertifikasyonun Batı Akdeniz Orman Ürünleri Sanayisi Üzerindeki Etkileri” ismiyle ve 19.5310/2018-2020 proje numarasıyla gerçekleştirilen araştırma sonucunda hazırlanan ve OGM Araştırma İhtisas Grupları Toplantısında yayınlanması yönünde karar verilen Proje Sonuç Raporunun (Y1lmaz ve ark., 2020) bir bölümünün özetidir. Araştırmaya, Batı Akdeniz bölgesindeki orta ve büyük ölçekli orman ürünleri sanayi temsilcileri, Batı Akdeniz Ormancılık Araştırma Enstitüsü Müdürlüğü, Antalya Orman Bölge Müdürlüğü ve orman ürünleri sanayindeki uzmanlar dâhil olmuştur. Çalışmaya verdikleri destek için tüm katılımcılara teşekkür ederiz.

\section{Kaynaklar}

Aguilar, F. X., Vlosky, R. P., 2007. Consumer Willingness to Pay Price Premiums for Environmentally Certified Wood Products in the U. S. Forest Policy and Economics, 9 (8): 1100-1112.

Akyol, A. ve Üçok, G., 2008. Sertifikasyon Kavramı ve Ülkemiz Ormancilı̆̆ında Durum. VI. Orman Fakülteleri Öğrenci Kongresi, 8-9 Mayıs 2008, Sayfa: 301-311, Düzce.
Alt, C., 2001. The Impact of Environmental Certification on U.S. Hardwood Flooring Manufacturers. Forest Products Marketing and Management, Virginia Polytechnic Institute and State University, 172 pages, USA.

Anderson, R. C., Hansen, E. N., 2004. Determining Consumer Preferences for Ecolabeled Forest Products. Journal of Forestry, 102 (4): 28-32.

Bartley, T., 2003. Certifying Forests and Factories: States, Social Movements, and the Rise of Private Regulations in the Apparel and Forest Products Fields. Polit. Soc., 31 (3): 433-464.

Bigsby, H., Ozanne, L. K., 2002. The Purchase Decision: Consumers and Environmentally Certified Wood Products. Forest Products Journal, 52 (7/8): 100-105.

Bowyer, J. L., 2008. The Green Movement and the Forest Products Industry. Forest Products Journal, 58 (7/8): 6-13.

Chen, J., Innes, J. L., Tikina, A., 2010. Private Cost-Benefits of Voluntary Forest Product Certification. International Forestry Review, 12 (1): 1-12.

Durst, P. B., Mckenzie, P. J., Brown, C. L., Appanah, S., 2006. Challenges Facing Certification and Eco-Labelling of Forest Products in Developing Countries. International Forestry Review, 8 (2): 193-200.

Dursun, Ö. ve Daşdemir, İ., 2016. The Impacts of FSC Certification Process on Keles Forest Enterprise. International Forestry Symposium (IFS 2016), Proceedings Book, pp.317-329, 07-10 December, Kastamonu University, Faculty of Forestry, Kastamonu-Turkey.

Dursun, Ö. ve Daşdemir, İ., 2017. İnegöl Orman İşletmesinde FSC Sertifikasyon Sürecinin Etkileri. Türkiye Ormancılar Derneği IV. Ulusal Ormancılık Kongresi, Bildiriler Kitabı, 15-16 Kasım, Antalya.

Durusoy, İ., 2002. Sertifikalandırma ve Türkiye Ormancıllı̆ında Gerekliliğii, Olabilirliğgi, Uygulanmas1 Sürecinde Karşılaşılması Muhtemel Darboğazların ve Firsatların İrdelenmesi. KTÜ Fen Bilimleri Enstitüsü, Yayınlanmamış Yüksek Lisans Tezi, 186 sayfa, Trabzon.

Ebeling, J., Yasue, M., 2009. The Effectiveness of Market-Based Conservation in the Tropics: Forest Certification in Ecuador and Bolivia. Journal of Environmental Management, (90): 1145-1153.

Forsyth, K., Haley, D., Kozak, R., 1999. Will Costumers Pay More for Certified Wood Products? Journal of Forestry, 97 (2): 18-22.

Genç, A., 2014. Orman Yönetim Sertifikası Uygulamalarında Karşılaşılan Sorunlar ve Çözüm Önerileri (Kastamonu Orman Bölge Müdürlüğü Örneği). Kastamonu Üniversitesi, Fen Bilimleri Enstitüsü, Orman Mühendisliği Anabilim Dalı, Yayınlanmamış Yüksek Lisans Tezi, 122 sayfa, Kastamonu.

Geray, U., 1999. Türkiye'de Orman Sertifikalandırma Olabilirlik Raporu. İ.Ü. Orman Fakültesi, Ormancılık 
Ekonomisi Anabilim Dalı, Haziran, 32 sayfa, İstanbul.

Hansen, E., 1997. Forest Certification and its Role in Marketing Strategy. Forest Products Journal, 47 (3): 16-22.

Hubbard, S. S., Bowe, S. A., 2005. Environmentally Certified Wood Products: Perspectives and Experiences of Primary Wood Manufactures in Wisconsin. Forest Products Journal, 55 (1): 33-40.

İlter, E. ve Ok, K., 2004. Ormancilık ve Orman Endüstrisinde Pazarlama İlkeleri ve Yönetimi (Örnek Olaylarla). 1. Basım, Form Ofset Matbaacılık, 488 sayfa, Ankara.

Jayasinghe, P., Allen, D. S., Bull, G. Q., Kozak, R. A., 2007. The Status of Forest Certification in the Canadian Value-Added Wood Products Manufacturing Sector. The Forestry Chronicle, 83 (1): 113-125.

Jensen, K., Jakus, P. M., English, B., Menard, J., 2003. Market Participation and Willingness to Pay for Environmentally Certified Products. Forest Science, 49 (4): 632-641.

Karagöz, F., 2010. Orman Koruma ve Gözetim Zinciri. Eko Yapı Dergisi, Cilt: 4, Sayfa: 104-108.

Karagöz, Ü., Kaymakçı, A., Bayram, B. Ç., Akyıldız, M. H., Ateş, S. ve Karagöz, F., 2011. Odun ve Odun Ürünlerinin Sertifikasyonu. I. Ulusal Akdeniz Orman ve Çevre Sempozyumu, 26-28 Ekim 2011, Tebliğler Kitabı, Sayfa: 709-719, Kahramanmaraş.

Kiekens, J. P., 2000. Forest Certification. Hardwood Plywood and Veneer Association, Quebec City, October 5, Canada.

Koç, M., 2016. Orman Ürünleri Pazarlarında Sertifikalı Ürünlerin Analizi. İstanbul Üniversitesi, Fen Bilimleri Enstitüsü, Orman Mühendisliği Anabilim Dalı, Yayınlanmamış Yüksek Lisans Tezi, 107 sayfa, İstanbul.

Koçak, S., 2016. Türkiye'de Orman Sertifikasyonu Uygulamalarının Orman Kaynaklarının Yönetimine Getirdiği Etkiler. Süleyman Demirel Üniversitesi, Fen Bilimleri Enstitüsü, Yayınlanmamış Yüksek Lisans Tezi, 76 sayfa, Isparta.

Koçak, S., Tolunay, A. ve Türkoğlu, T., 2017. Türkiye'de Orman Sertifikasyonu Uygulamalarının Orman Kaynakları Yönetimine Etkileri. Türkiye Ormancılık Dergisi, Cilt: 18, Sayı: 1, Sayfa: 49-56, Isparta.

Komut, O., 2016. Türkiye'de Ormancılık ve Orman Ürünleri Endüstrisinde Sertifikasyon: Sektörel Durum ve Farkındalık Çözümlemesi. Artvin Çoruh üniversitesi, Fen Bilimleri Enstitüsü, Orman Mühendisliği Anabilim Dalı, Yayınlanmamış Doktora Tezi, 214 sayfa, Artvin.

Kozak, R. A., Cohen, D. H., Lerner, J., Bull, G. Q., 2004. Western Canadian Consumer Attitudes towards Certified Value-Added Wood Products: An Exploratory Assessment. Forest Products Journal, 54 (9): 21-24.

Kumar N. V., Ganesh, L. S., 1996. A Simulation-Based
Evaluation of the Approximate and Exact Eigenvector Methods Employed in AHP. European Journal of Operational Research, (95): 656-662.

Lee, L. M., 1995. A Methodology for Generating Alternative Land Use Plans Using GIS Modeling Techniques. Thesis (PhD), University of Washington, Washington, 201 pages, U.S.A.

Mohamed, S., Ibrahim, M. L., 2007. Preliminary Study on Willingness to Pay for Environmentally Certified Wood Products among Consumers in Malaysia. Journal of Applied Sciences, 7 (9): 1339-1342.

Myers, J. H., Alpert, M. I., 1968. Determinant Buying Attitudes: Meaning and Measurement. Journal of Marketing, July, (32): 13-20.

Ozanne, L. K., Vlosky, R. P., 1997. Willingness to Pay for Environmentally Certified Wood Products: A Consumer Perspective. Forest Products Journal, 47 (6): 39-48.

Ozanne, L. K., Vlosky, R. P., 2003. Certification from the US Consumer Perspective: A Comparison from 1995 and 2000. Forest Products Journal, 53 (3): 13-21.

Rametsteiner, E., Simula, M., 2003. Forest Certification An Instrument to Promote Sustainable Forest Management? Journal of Environmental Management, 67 (1): 87-98.

Ratnasingam, J., Macpherson, T. H., Joras, F., 2008. An Assessment of Malaysian Wooden Furniture Manufacturers' Readiness to Embrace Chain of Custody $(\mathrm{CoC})$ Certification. European Journal of Wood and Wood Products, (66): 339-343.

Saaty, T. L., 1977. A Scaling Method for Priorities in Hierarchical Structures. Journal of Mathematical Psychology, (15): 234-281.

Saaty, T. L., 1980. The Analytic Hierarchy Process Planning, Priority Setting, Resource Allocation. McGraw-Hill, New York, U.S.A.

Saaty, T. L., 1990. How to Make a Decision: The Analytic Hierarchy Process. European Journal of Operations Research, (48): 9-26.

Saaty, T. L., 1994. How to Make a Decision: The Analytic Hierarchy Process. Interfaces, No: 6, (24): 19-43.

Schmoldt, D. L., Peterson, D. L., Smith, R. L., 1994. The Analytic Hierarchy Process and Participatory Decision Making. Proceedings from Decision Support 2001, Volume: 1, 17th Annual Geographic Information Seminar and the Resource Technology 94 Symposium, Toronto, Ontario, September 12-16, 1994.

Stevens, J., Ahmad, M., Ruddell, S., 1998. Forest Products Certification: A Survey of Manufacturers. Forest Products Journal, 48 (6): 43-49.

Şener F.N., 2009. Türkiye‘de Sürdürülebilir Ormancılık Uygulamalarının Sertifikasyon ve Akreditasyonunda Sivil ve İdari Yapılanma [Andırın Devlet Orman İşletme Müdürlüğü ve Göksun Devlet Orman İşletme 
Müdürlüğü Örneği (2003-2007)]. KSÜ, Fen Bilimleri Enstitüsü, Yayınlanmamış Yüksek Lisans tezi, 114 sayfa, Kahramanmaraş.

Şener, F. N., 2016. Sürdürülebilir Orman Yönetimi Süreçlerinde Türkiye'nin Konum Analizi. Süleyman Demirel üniversitesi, Fen Bilimleri Enstitüsü, Yayınlanmamış Doktora Tezi, 326 sayfa, Isparta.

Şener, F. N., Tolunay, A. ve Görücü, Ö., 2011. Sürdürülebilir Ormancılık Uygulamalarında Sertifikasyon ve Akreditasyon: Andırın ve Göksun Devlet Orman İşletme Müdürlükleri Örneği. SDÜ Orman Fakültesi Dergisi, Cilt: 12, Sayfa: 115-125.

Şensöz, İ. H., 2014. Ormancilıkta Sertifikasyon ve Ormancılık Politikası Açısından Önemi. İ.Ü. Fen Bilimleri Enstitüsü, Yayınlanmamış Yüksek Lisans Tezi, 98 sayfa, İstanbul.

Tikina, A. V., Innes, J. L., 2008. A Framework for Assessing the Effectiveness of Forest Certification. Canadian Journal of Forest Research, 38 (6): 1357-1365.

Türker M. F., Başkent E. Z. ve Durusoy İ., 2001. Ormancılıkta Sertifikasyon: Orman Kaynakları ve Orman İşletmeciliği Üzerine Etkileri, Uluslararası Gelişmeler ve Türkiye Ormancılığında Gerekliliğgi ve Olabilirliği. I. Ulusal Ormanc1lık Kongresi, Türkiye Ormanc1lar Derneği Yayın1, Kongre Serisi No: 1, Sayfa: 294-305, Ankara.

Türkoğlu, T., 2009. Türkiye'de Ormanların ve Orman Ürünlerinin Sertifikalandırılması. II. Ormancilıkta Sosyo-Ekonomik Sorunlar Kongresi, 19-21 Şubat 2009, SDÜ, Tebliğler Kitabı, Sayfa: 378-388, Isparta.

Türkoğlu, T., 2011. Türkiye'deki Orman Endüstrisi İşletmelerine Sürdürülebilir Orman Yönetimi Çerçevesinde Odun Hammaddesi Tedariki ve Orman Ürünlerinin Sertifikasyonu. Süleyman Demirel Üniversitesi, Fen Bilimleri Enstitüsü, Yayınlanmamış Doktora Tezi, 243 sayfa, Isparta.

Türkoğlu, T. ve Tolunay, A., 2013. Türkiye'deki Orman Ürünleri İthalatçısı İşletmelerin Sertifikalı Orman Ürünlerine İlişkin Görüşleri. SDÜ Orman Fakültesi
Dergisi, Cilt: 14, Sayfa: 95-101.

Türkoğlu, T. ve Tolunay, A., 2014. FSC Orman Yönetim Sertifikasının Muğla Ormanlarına Etkisinin Nitel Olarak Araştırılması. II. Ulusal Akdeniz Orman ve Cevre Sempozyumu, "Akdeniz ormanlarının geleceği: Sürdürülebilir toplum ve çevre", 22-24 Ekim 2014, Tebliğler Kitab1, Sayfa: 506-517, Isparta.

Vidal, N., Kozak, R., Cohen, D., 2005. Chain of Custody Certification: An Assessment of the North American Solid Wood Sector. Forest Policy and Economics, 7 (3): 345-355.

Vlosky, R. P., Ozanne, L. K., 1998. Environmental Certification of Wood Products: The U. S. Manufacturers' Perspective. Forest Products Journal, 48 (9): 21-26.

Vurdu, H., Ayan, S., Küçük, Ö. 2007. Yerel ve Piyasa Tabanlı Önlemlere Yönelik Karadeniz Bölgesi Koruma ve Ormancılık Bilgi Ağının Kurulması. Teknopaket, 376 sayfa, Kastamonu.

Yılmaz, E., 1999. Analitik Hiyerarşi Süreci Kullanılarak Çok Kriterli Karar Verme Problemlerinin Çözümü. DOA Dergisi, No: 5, Doğu Akdeniz Ormancılık Araştırma Enstitüsü Yayın1, Sayfa: 95-122, Tarsus.

Y1lmaz, E., 2005. Analitik Hiyerarşi Süreci Tekniği ve Orman Kaynakları Planlamasına Uygulanması Örnekleri. DOA Dergisi, No: 11, Doğu Akdeniz Ormancılık Araştırma Enstitüsü Yayını, Sayfa: 1-33, Tarsus.

Y1lmaz, E., Coşgun, U., Koçak, Z., Ay, Z., Orhan, K. H., 2009. Katılımcı Yaklaşımla Ekoturizm Stratejilerinin Belirlenmesi ve Önceliklendirilmesi: Cehennemdere Vadisi ve Köprülü Kanyon Milli Park1 Örnekleri. T.C. Çevre ve Orman Bakanlığı, Doğu Akdeniz Ormancılık Araştırma Müdürlüğü, Teknik Bülten, Tarsus, pp: 78.

Yllmaz, E., Alkan, S., Kayacan, A., Bayir, Y., Mavi, Z., 2020: Sertifikasyonun Batı Akdeniz Orman Ürünleri Sanayisi Üzerindeki Etkileri. T.C. Tarım ve Orman Bakanlığ1, Batı Akdeniz Ormancılık Araştırma Enstitüsü Müdürlüğü, Sonuçlanan Proje Sonuç Raporu, 100 sayfa, Antalya. 